\title{
Can Intestinal Constipation Be Modulated by Prebiotics, Probiotics and Symbiotics?
}

\author{
Mônica de Souza Lima Sant'Anna ${ }^{1 *}$, Célia Lúcia de Luces Fortes Ferreira ${ }^{2}$ \\ ${ }^{1}$ Departament of Nutrition, Federal University of Sergipe, São Cristovão, Brazil \\ ${ }^{2}$ Department of Food Technology, Federal University of Viçosa, Viçosa, Brazil \\ Email: " monicaslsantana@gmail.com, clferrei@ufv.br
}

Received 29 March 2014; revised 3 May 2014; accepted 12 May 2014

Copyright @ 2014 by authors and Scientific Research Publishing Inc.

This work is licensed under the Creative Commons Attribution International License (CC BY).

http://creativecommons.org/licenses/by/4.0/

(c) (i) Open Access

\begin{abstract}
The importance of maintaining a healthy intestinal microbiota in the health of the host has been increasingly clarified. This microbiota may appear unbalanced in diseases such as colitis, diarrhea, irritable bowel syndrome and constipation. To rebalance the microbiota and improve the symptoms of constipation, it is recommended to intake prebiotics, probiotics and symbiotics, which works in the modulation of a healthy intestinal microbiota and favors the production of shortchain fatty acids that have a positive effect on intestinal transit. In addition, some studies indicate that there is a relation between the brain and the intestine that influences the behavior of individuals with intestinal dysbiosis. Thus, the reestablishment of the eubiosis in constipated patients through the functional compounds (prebiotics, probiotics and symbiotics) has been showing promising results regarding the modulation of constipation and improvement of the clinical picture. This review will emphasize the relation of prebiotics, probiotics and symbiotics in the modulation of intestinal constipation. New food sources of these compounds should be evaluated for their efficacy, dose and effect to establish a proper management.
\end{abstract}

\section{Keywords}

Intestinal Microbiota, Fructooligosaccharides, Inulin, Constipation

\section{Introduction}

Intestinal constipation is a chronic disease that affects about $16 \%$ of the world population, with higher prevalence in females and after the age of 65. One of the major problems of constipation is that the available therapies, such as high fibre diet, use of medicines, and higher water intake, are not satisfactory in at least one third of the patients [1].

\footnotetext{
${ }^{*}$ Corresponding author.
} 
The constipation is characterized by the following symptoms: less than 3 evacuations per week, the feeling of incomplete emptying, the straining to evacuate, and the presence of hardened and fragmented feces [2].

One of the consequences of constipation is intestinal dysbiosis, which is characterized by an increase of undesirable bacteria in the intestine and a decline of beneficial bacteria. The imbalance can affect the motility of the large intestine by modifying the metabolic environment of the colon due to the increase of the $\mathrm{pH}$ generated by undesirable bacteria, which causes a consequent reduction in the production of physiologically active beneficial compounds [3] due to the synthesizing of toxic substances, such as phenols, ammonia and pro-carcinogenic substances [4]. The products of balanced colonic fermentation, such as short-chain fatty acids (SCFA), modulate the motility by exerting a trophic effect on the epithelial cells, increasing the blood flow in the region [5].

To reestablish a healthy microbiota, the intake of probiotics and/or soluble fibre with prebiotic effects is recommended, such as inulin and fructooligosaccharides (FOS) that stimulate the growth of bacteria from the ileum and especially in the colon, where lactobacilli and bifidobacteria are respectively preferred. As a product of the beneficial fermentation, SCFA are produced, mainly the butyrate, which has proven its effect on the desired modulation of intestinal motility [4] [6].

In this review, the variables related to the control of constipation will be emphasized, which are: the importance of a balanced microbiota, the relation between constipation and the "gut-brain axis", and the functional compounds that modulate the microbiota, reducing the risk of constipation.

The authors carried out a search on the main scientific databases (Science Direct, PubMed, Google Scholar) with the following descriptors: "intestinal constipation", “microbiota”, "gut-brain-axis", "prebiotics", "probiotics", "symbiotics". The research expressions were constructed by combining these terms or using each one in isolation.

\section{Intestinal Microbiota and Constipation}

Intestine colonization begins immediately after birth. The intestinal microbiota composition of children is relatively simple, with a limited number of microbial groups, such as Bacteroides and Bifidobacterium [7], but it becomes more complex as age increases [8]. Changes in the microbiota can be observed as a result of variations on the diet [9], pathological conditions (intestinal constipation, colitis) [10], antibiotics treatment and immunosuppression [11].

Skin surfaces and mucosa of the human body are colonized by micro-organisms from the environment, therefore constituting highly complex ecosystems. Particularly, the gastrointestinal tract (GT) holds the highest number of these micro-organisms [12]. Microbiota distribution varies according to the GT sections, presenting low concentrations of bacteria in the stomach and duodenum (up to $10^{3} \mathrm{CFU} / \mathrm{ml}$ ), with higher concentration in the jejunum and ileum $\left(10^{4}-10^{8} \mathrm{CFU} / \mathrm{ml}\right)$, reaching the highest concentrations in the colon (up to $10^{14} \mathrm{CFU} / \mathrm{ml}$ ), which surpasses the total number of eukaryotic cells in the human body [13]. The intestinal microbiota includes nearly 1000 species of bacteria with more than 7000 strains [14] [15]. The most common genus is anaerobic bacteria including Bifidobacterium, Lactobacilli, Clostridium, Bacteroides and Eubacterium. Facultative aerobic strains, such as Escherichia, Enterococcus, Streptococcus, and Klebsiella [15], are also found.

It is well documented that the microbiota is essential for intestinal development, promoting homeostasis and protecting the host against pathogenic micro-organisms [16]. In particular, the microbiota is involved in the functional dietary fiber fermentation (lactulose, resistant starch, oligosaccharides) [17]. When non-digestible carbohydrates are fermented by the microbiota, they form acids that can be absorbed by the mucosa. This process is called energetic saving, and it forms the SCFA, which are the main energy source of the colonocytes, acting on the trophic effect of the intestinal epithelium [7]. Anaerobic metabolism of peptides and proteins by the microbiota also produce SCFA, but, at the same time, generate a number of potentially toxic substances, including ammonia, amines, phenols, thiols, and indols [18]. Therefore, SCFA production through non-digestible carbohydrates fermentation is more interesting due to the fact it does not form toxic products that can cause damage to the intestinal epithelium.

SCFA perform other important functions in the host physiology. As mentioned above, the butyrate is almost completely consumed by the epithelium of the colon, and is an important energy source for colonocytes [19]. Aside from butyrate, acetate and propionate are found among the blood stream. Among its benefits is the fact that they are metabolized by the liver (propionate) or in the peripheral tissues, particularly on the muscle tissue (acetate) [20]. These acids can act as modulators of glucose metabolism, improving insulin sensitivity [21]. Studies [20] [22] show that the ideal proportion of acetate, propionate and butyrate in the colon is 2:1:1, respectively. 
In situations of dysbiosis, there is a decrease on the proportion of SCFA and a consequent increase on the production of branched-chain fatty acids, ammonia and phenols that indicate a change in the microbiota activity, passing from a condition of saccharolytic fermentation to a putrefactive microbial metabolism [23]. This metabolic change is common in cases of constipation [24].

\section{3. "Gut-Brain Axis" and Constipation}

Two-way signaling between the brain and the intestine is vital to homeostasis control and is regulated by the central nervous system. An imbalance in this axis results in changes in the stress response and, generally, in behavior [25]. Some psychiatric comorbidities, including stress, are related to gastrointestinal disorders, such as irritable bowel syndrome and inflammatory bowel disorder [26]. The right mechanisms that regulate this axis are not fully elucidated, and most studies focus on the change of signaling from the brain to the intestine [27]. However, recent studies have been investigating the impact of intestinal microbiota on the brain and behavior [28].

It is well documented that the microbiota can directly influence on intestinal homeostasis by regulating its motility [29]. For example, bacteria of the genera Bifidobacterium and Lactobacilli are able to promote motility by fermenting non-digestible carbohydrates and producing SCFA, whereas Escherichia species can inhibit motility [30] by not producing these compounds. Therefore, the disturbance of the microbiota balance may predispose the host to change the motility, resulting in diarrhea, common in irritable bowel syndrome, or constipation [25].

Patients with chronic intestinal constipation may present imbalance in the microbiota, characterized by a relative decrease of beneficial bacteria and an increase of potentially pathogenic bacteria and fungi [31]. These modifications may alter the concentrations of physiologically active substances, such as SCFA, which can influence on the motor function of the intestine [31].

Studies have shown an imbalance on the microbiota of constipated individuals and have found significant increase in the calculation of E. coli, S. aureus and enterobacteria in patients with chronic constipation [31]. The authors of this study report that the longer the disease installation is, the higher are the scores of undesirable micro-organisms, and the smaller are the scores of the desirable ones. In a study with children diagnosed with chronic constipation [32] a typical frame of intestinal dysbiosis was found on the feces, with a significant increase in the counting of the bacteria of genera Clostridium, Bacteroides and E. coli.

A French study [33] has found a significant decrease in the count of bifidobacteria and lactobacillus in feces of constipated individuals; such decrease is up to ten times lower for the Bifidobacterium genus.

In recent years, scholars have noticed an association between emotional components and intestinal constipation, such as the presence of stress, anorexia, depression, anxiety and hypochondria [34] [35]. Investigating the relation between these emotional symptoms and the microbia imbalance in constipated patients can be subject to oncoming studies.

In order to better illustrate this relation according to the results of different research studies, a figure was adapted to represent the "gut-brain axis" in constipation (Figure 1).

Figure 1 shows the main factors related to the intestinal motility. As already mentioned, the motility is decreased when there is an imbalance in the intestinal bacteria due to the inadequate production of substances that modulate the intestinal transit, such as butyrate. The question that may rise by the analysis of the figure is if the intestinal dysbiosis present in constipation is related to the emergence of psychosomatic problems reported by patients with constipation, which can even influence the quality of life [38].

\section{The Use of Prebiotics, Probiotics and Symbiotic in Constipation}

Prebiotics are defined as non-digestible food ingredients that benefit the host by selectively stimulating the growth and/or activity of a limited number of bacterial species in the colon, improving the health of the host [39]. In order to be considered prebiotic, it is necessary to scientifically demonstrate that the component, food or ingredient resist the digestion, absorption and adsorption processes of the host, be fermented by the microbiota that colonizes the gastrointestinal tract and selectively stimulate the growth and/or activity of beneficial bacteria [40]. Usually a beneficial change means the decrease of microbial groups considered undesirable (Clostridium, Bacteroides) and increase of desirable ones (Bifidobacterium, Lactobacillus). 


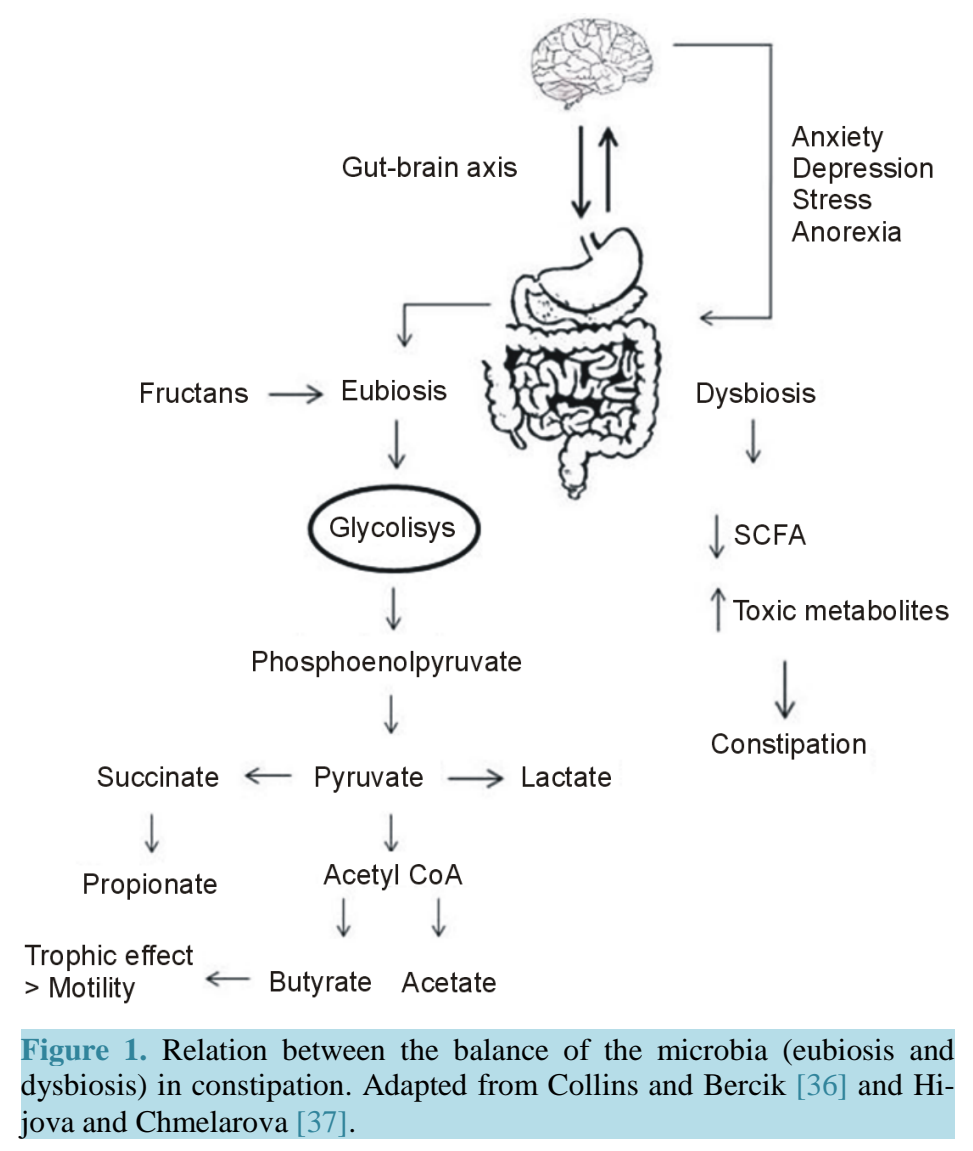

Probiotics are defined as living organisms that, when ingested in adequate quantities, have a beneficial effect to the health of the host [24]. Symbiotics are characterized by the combination of a prebiotic and a probiotic aiming to increase the survival and activity of probiotic strains evidenced in "in vivo" researches and still stimulate the growth of endogenous bacteria, in particular the bifidobacteria and the lactobacilli [24]. The ingestion of symbiotic modifies the microbiota composition, restoring the balance, which may have positive effects on gastrointestinal functions [41].

The consequences of the state of imbalance of the intestinal microbiota and the loss of its homeostasis show the importance of maintaining its normality and balance [42]. One of the therapeutic approaches to improve and maintain balance of the healthy microbiota involves the manipulation of the energy sources for these bacteria, i.e., the administration of prebiotics that stimulate the probiotic bacteria already present in the colon (endogenous). Another strategy would be the administration of symbiotic that, aside from the prebiotic, provides a beneficial bacteria, generally of the Bifidobacterium genus, adapted to the ecological niche that, even temporarily, changes the $\mathrm{pH}$ to inadequate levels for the proliferation of putrefactive microorganisms.

Virtually, any carbohydrate that reaches the large intestine will provide substrate to the commensal microbiota, affecting its growth and metabolic activity. This effect has been demonstrated mainly by the soluble fibers, resistant starches, oligosaccharides and disaccharides such as lactulose [17]. The selective properties of the prebiotics are mainly related to the growth of bifidobacteria and lactobacilli in detriment of other bacterial groups, such as bacteroids and clostridia [43].

Most prebiotic, probiotic and symbiotic benefits for the intestinal health come from studies with animals or clinical research studies with a limited number of individuals [24].

In assessing the effect of $20 \mathrm{~g}$ lactulose/day for 30 days in the intestinal microbiota of individuals with chronic constipation, the authors found a higher bifidobacteria count, higher concentrations of butyrate and acetate and higher fecal mass in the group that received the lactulose with regard to the placebo [10].

In a study conducted in Germany [44], constipated elderly received $20 \mathrm{~g}$ of inulin per day for 19 days. There was an increased count of bifidobacteria and a decreased count of enterobacteria and enterecocos, besides the 
increase in the number of evacuations during the week. The authors did not find differences in the fecal pH and in the concentration of short-chain fatty acids between the study group and the placebo. Clinical benefits have been observed in elderly that were institutionalized with diagnosis of constipation when $10 \mathrm{~g}$ FOS/day were administered for 4 weeks [45]. The authors found a significant increase in the counting of bifidobacteria in fecal samples in the FOS group in relation to the control. The authors also evaluated the bifidogenic effect after FOS retrieval and found the maintenance of this effect for up to 4 weeks. This finding is of utmost importance, since the majority of the researches indicate that the FOS bifidogenic effect is maintained only during its regular consumption, ceasing after the removal of the prebiotic. It is important to know the acting period of these different prebiotics to contribute to the management of the indication and of their use. A research conducted in Brazil [4] evaluated a mixture of inulin and guar gum partially hydrolyzed in 60 constipated women who consumed $15 \mathrm{~g}$ of this mixture during 3 weeks. The authors found improvements in the frequency of evacuations and also a significant decrease in the fecal counting of bacteria of the Clostridium genus when compared to the placebo. No significant difference was found in the concentration of SCFA.

A randomized, double blind research [46] evaluated the effect of a fermented product with the addition of probiotic (Bifidobacteriumlactis) in 34 patients with diagnosis of irritated bowel syndrome with constipation. The authors observed the acceleration of the intestinal transit time in the group that received the probiotic when compared to the placebo. Also, in a study with 70 individuals with diagnosis of chronic constipation, a drink source of probiotic (Lactobacillus casei Shirota) was effective in increasing the number of evacuations on those who received the drink with the addition of the microorganism [47].

In a Finnish study [48] with constipated elderly, two strains of the Lactobacillus rhamnosus and Propionibacterium freudenreichii species were added to orange juice samples that were provided to volunteers for 3 weeks. A positive effect in the frequency of evacuations, which were 3 times higher than in the control group, was observed. In relation to the effect of the symbiotic in constipation, Amenta et al. [49] evaluated the effect of a symbiotic supplement composed by FOS and Bifidobacterium longum in 297 patients for 60 days, observing an increase in the number of evacuations. Another study conducted in Brazil [50] found positive effect in the consumption of a product containing FOS (6 g) and bacteria from the Lactobacillus paracasei, Lactobacillus rhamnosus, Lactobacillus acidophiluse, Bifidobacterium lactis strains in 49 women with diagnosis of constipation. There was an increase in the number of evacuations without side effects (flatulence, abdominal distension and pain) in patients that consumed the product.

Evaluating the described studies, it is possible to notice that the prebiotics, the probiotics and the symbiotics are effective in improving the intestinal transit of constipated individuals. However, the sources of prebiotic in use are purified compounds, such as the FOS, the inulin and the lactose, and not a source food of these ingredients, beneficial to intestinal health.

Since it is a source of FOS and inulin, the yacon roots and their sub-products can potentially be used as a source of prebiotics in the diet. The in natura yacon stands out due to its high water content, which can exceed more than $90 \%$ of its fresh weight [51]. This characteristic makes the root highly perishable. Thus, it is of upmost importance the development of products that can decrease this perishability and also make the product available throughout the whole year, since the root is seasonal.

In this context, the identification of novel foods and functional ingredients that are source of prebiotics is important to evaluate their potential effect in the prevention of specific deceases. One of these foods is the yacon (Smallanthus sonchifolius), a source particularly abundant of FOS and inulin [52].

The consumption of moderate quantities of products made of roots of yacon is related to the reduction of the plasmatic levels of blood glucose [53] [54], reduction of the triacylglycerols levels [55], increase in the absorption of calcium and magnesium [56] [57] and improvement of the intestinal constipation [53] [58].

\section{Final Considerations}

It has been recognized that maintaining a healthy intestinal microbe has a positive influence in health. Thus, eating sources of prebiotics, probiotics and symbiotics can be considered as an important tool in the maintenance of the microbiota in a way that the harmful bacterial strains should be deleted, and the beneficial, stimulated. Such modulation of the microbial population can be made through the consumption of foods containing prebiotics, probiotics and/or symbiotic compounds. Some preliminary results of investigations of the effects of these functional compounds in health have been promising; however, some claims must be verified through tests in 
humans, particularly in regard to the dose to be consumed, the frequency of consumption and the maintenance of the post-consumption effects.

\section{References}

[1] Camilleri, M. and Bharucha, A.E. (2010) Behavioural and New Pharmacological Treatments for Constipation: Getting the Balance Right. Gut, 59, 1288-1296. http://dx.doi.org/10.1136/gut.2009.199653

[2] Drossman, D.A. (2006) Rome III: The New Criteria. Chinese Journal of Digestive Diseases, 7, 181-185.

[3] Gerritsen, J., Smidt, H., Rijkers, G.T. and De Vos, W.M. (2011) Intestinal Microbiota in Human Health and Disease: The Impact of Probiotics. Genes \& Nutrition, 6, 209-240.

[4] Waitzberg, D.L., Pereira, C.C., Logullo, L.C., Jacintho, M.T., Almeida, D., Silva, M.L.T. and Torrinhas, R.S. (2012) Microbiota Benefits after Inulin and Partially Hydrolized Guar Gum Supplementation-A Randomized Clinical Trial in Constipated Women. Nutricion Hospitalaria, 27, 123-129.

[5] Ducrotté, P. (2010) Microbiota and Irritable Bowel Syndrome. Gastroentérologie Clinique et Biologique, 34, S52-S56. http://dx.doi.org/10.1016/S0399-8320(10)70021-X

[6] Macfarlane, S., Macfarlane, G.T. and Cummings, J.H. (2006) Review Article: Prebiotics in the Gastrointestinal Tract. Alimentary Pharmacology \& Therapeutics, 24, 701-714. http://dx.doi.org/10.1111/j.1365-2036.2006.03042.x

[7] Brandt, K.G., Sampaio, M.C. and Miuki, C.J. (2006) Importância da Microflora Intestinal. Pediatria, 28, 117-127.

[8] Blaut, M. (2002) Relationship of Prebiotics and Food to Intestinal Microflora. European Journal of Nutrition, 41, i11i16. http://dx.doi.org/10.1007/s00394-002-1102-7

[9] Schiffrin, E.J. and Blum, S. (2002) Interactions between the Microbiota and Theintestinal Mucosa. European Journal of Clinical Nutrition, 56, 60-64. http://dx.doi.org/10.1038/sj.ejcn.1601489

[10] Bouhnik, Y., Raskine, L., Simoneau, G., Vicaut, E., Neut, C., Flourie, B., Brouns, F. and Bornet, F.R. (2004) The Capacity of Nondigestible Carbohydrates to Stimulate fecal Bifidobacteria in Healthy Humans, a Double-Blind, Randomized, Placebo-Controlled, Parallel-Group, Dose-Response Relation Study. American Journal of Clinical Nutrition, 80, 1658-1664.

[11] Manhart, N., Spittler, A., Bergmeister, H., Mittlbock, M. and Roth, E. (2003) Influence of Fructooligosaccharides on Peyer's Patch Lymphocyte Numbers in Healthy and Endotoxemic Mice. Nutrition, 19, 657-660. http://dx.doi.org/10.1016/S0899-9007(03)00059-5

[12] Hooper, L.V., Midtvedt, T. and Gordon, J.I. (2002) How Host-Microbial Interactions Shape the Nutrient Environment of the Mammalian Intestine. Annuals Reviews of Nutrition, 22, 283-307.

[13] Montalto, M., Onofrio, F.D., Gallo, A., Cazzato, A. and Gasbarrini, G. (2009) Intestinal Microbiota and Its Functions. Digestive and Liver Disease Supplements, 3, 30-34. http://dx.doi.org/10.1016/S1594-5804(09)60016-4

[14] Ley, R.E., Peterson, D.A. and Gordon, J.I. (2006) Ecological and Evolutionary Forces Shaping Microbial Diversity in the Human Intestine. Cell, 124, 837-848. http://dx.doi.org/10.1016/j.cell.2006.02.017

[15] Hattori, M. and Taylor, T.D. (2009) The Human Intestinal Microbiome: A New Frontier of Human Biology. DNA Research, 16, 1-12. http://dx.doi.org/10.1093/dnares/dsn033

[16] O’Hara, A.M. and Shanahan, F. (2006) The Gut Flora as a Forgotten Organ. EMBO Reports, 7, 688-693. http://dx.doi.org/10.1038/sj.embor.7400731

[17] Magalhães, M.S., Salminen, S., Tommola, J., Collado, M.C., Ferreira, C.L., Anna, P. and Marchelli, R. (2011) Prebiotic. In: Magalhães, M.S., Salminen, S., Anna, P., Marchelli, R., Ferreira, C.L. and Tommola, J., Eds., Terminology, University of Turku, Turku, 50-65.

[18] Macfarlane, G.T., Cummings, J.H. and Allison, C. (1986) Protein Degradation by Human Intestinal Bacteria. Journal of General Microbiology, 132, 1647-1656.

[19] Hamer, H.M., Jonkers, D., Venema, K., Vanhoutvin, S., Troost, F.J. and Brummer, R.J. (2008) Review Article: The Role of Butyrate on Colonic Function. Alimentary Pharmacology \& Therapeutics, 27, 104-119. http://dx.doi.org/10.1111/j.1365-2036.2007.03562.x

[20] Cummings, J.H. and Englyst, H.N. (1987) Fermentation in the Human Large Intestine and the Available Substrates. American Journal of Clinical Nutrition, 45, 1243-1255.

[21] Guarner, F. and Malagelada, J.R. (2003) Gut Flora in Health and Disease. The Lancet, 361, 512-519. http://dx.doi.org/10.1016/S0140-6736(03)12489-0

[22] Gibson, G.R., Beatty, E.R., Wang, X. and Cummings, J.H. (1995) Selective Stimulation of Bifidobacteria in the Human Colon by Oligofructose and Inulin. Gastroenterology, 108, 975-982. http://dx.doi.org/10.1016/0016-5085(95)90192-2 
[23] Woodmansey, E.J. (2007) Intestinal Bacteria and Ageing. Journal of Applied Microbiology, 102, 1178-1186. http://dx.doi.org/10.1111/j.1365-2672.2007.03400.x

[24] Quigley, E.M.M. (2011) The Enteric Microbiota in the Pathogenesis and Management of Constipation. Best Practice \& Research Clinical Gastroenterology, 25, 119-126. http://dx.doi.org/10.1016/j.bpg.2011.01.003

[25] Rhee, S.H., Pothoulakis, C. and Mayer, E.A. (2009) Principles and Clinical Implications of the Brain-Gut-Enteric Microbiota Axis. Nature Reviews Gastroenterology \& Hepatology, 6, 306-314. http://dx.doi.org/10.1038/nrgastro.2009.35

[26] Camara, R.J., Ziegler, R., Begré, S., Schoepfer, A.M. and Von Känel, R. (2009) The Role of Psychological Stress in Inflammatory Bowel Disease: Quality Assessment of Methods of 18 Prospective Studies and Suggestions for Future Research. Digestion, 80, 129-139. http://dx.doi.org/10.1159/000226087

[27] Bonaz, B. and Sabate, J.M. (2009) Brain-Gut Axis Dysfunction. Gastroentérologie Clinique et Biologique, 33, S48S58. http://dx.doi.org/10.1016/S0399-8320(09)71525-8

[28] Denou, E., Bercik, P. and Collins, S.M. (2010) Perturbation of the Intestinal Microbiota Alters Behavior in Mice. Gastroenterology, 136, 776-787.

[29] Husebye, E., Hellström, P.M., Sundler, F., Chen, J. and Midtvedt, T. (2001) Influence of Microbial Species on Small Intestinal Myoelectric Activity and Transit in Germ-Free Rats. American Journal of Physiology, Gastrointestinal and Liver Physiology, 280, G368-G380.

[30] Mazmanian, S.K. Round, J.L. and Kasper, D.L. (2008) A Microbial Symbiosis Factor Prevents Intestinal Inflammatory Disease. Nature, 453, 620-625. http://dx.doi.org/10.1038/nature07008

[31] Khalif, I.L., Quigley, E.M.M., Konovitch, E.A. and Maximova, I.D. (2005) Alterations in the Colonic Flora and Intestinal Permeability and Evidence of Immune Activation in Chronic Constipation. Digestive and Liver Disease, 37, 838849. http://dx.doi.org/10.1016/j.dld.2005.06.008

[32] Zoppi, G., Cinquetti, M., Luciano, A., Benini, A., Miner, A. and Bertazzoni, M.E. (1998) The Intestinal Ecosystem in Chronic Functional Constipation. Acta Paediatrica, 87, 836-841.

[33] Chassard, C., Dapoigny, M., Scott, K.P., Crouzet, L., Del’homme, C., Marquet, P., Martin, J.C., Pickering, G., Ardid, D., Eschalier, A., Dubray, C., Flint, H.J. and Bernalier-Donadille, A. (2012) Functional Dysbiosis within the Gut Microbiota of Patients with Constipated-Irritable Bowel Syndrome. Alimentary Pharmacology \& Therapeutics, 35, 828838. http://dx.doi.org/10.1111/j.1365-2036.2012.05007.x

[34] Nogueira, G.S., Zanin, C.R. and Gomes, J. (2010) Intervenção Cognitivo-Comportamental em Paciente com Constipação Intestinal: Relato de Caso. Revista Brasileira de Terapias Cognitivas, 6, 138-154.

[35] Devroede, G., Girard, G., Bouchoucha, M., Roy, T., Black, R., Camerlain, M., et al. (1989) Idiopathic Constipation by Colonic Dysfunction. Relationship with Personality and Anxiety. Digestive Diseases and Sciences, 34, 1428-1433. http://dx.doi.org/10.1007/bf01538081

[36] Collins, S.M. and Bercik, P. (2009) The Relationship between Intestinal Microbiota and the Central Nervous System in Normal Gastrointestinal Function and Disease. Gastroenterology, 136, 2003-2014. http://dx.doi.org/10.1053/j.gastro.2009.01.075

[37] Hijova, E. and Chmelarova, A. (2007) Short Chain Fatty Acids and Colonic Health. Bratisl Lek Listy, 108, $354-358$.

[38] Irvine, E.J., Ferrazzi, S., Pare, P., Thompson, W.G. and Rance, L. (2002) Health-Related Quality of Life in Functional GI Disorders: Focus on Constipation and Resource Utilization. The American Journal of Gastroenterology, 97, 19861993. http://dx.doi.org/10.1111/j.1572-0241.2002.05843.x

[39] Roberfroid, M. (2007) Prebiotics: The Concept Revisited. The Journal of Nutrition, 137, 830S-837S.

[40] Laparra, J.M. and Sanz, Y. (2010) Interactions of Gut Microbiota with Functional Food Components and Nutraceuticals. Pharmacological Research, 61, 219-225. http://dx.doi.org/10.1016/j.phrs.2009.11.001

[41] Morelli, L., Zonenschain, D., Callegari, M.L., Grossi, E., Maisano, F. and Fusillo, M. (2003) Assessment of a New Synbiotic Preparation in Healthy Volunteers: Survival, Persistence of Probiotic Strains and Its Effect on the Indigenous Flora. Nutrition Journal, 2, 11.

[42] Almeida, L.B., Marinho, C.B., Souza, C.S. and Cheib, V.B.P. (2009) Disbiose Intestinal. Revista Brasileira de Nutrição Clinica, 24, 58-65.

[43] Cummings, J.H. and Macfarlane, G.T. (2002) Gastrointestinal Effects of Prebiotics. British Journal of Nutrition, 87, S145-S151. http://dx.doi.org/10.1079/BJN/2002530

[44] Kleessen, B., Svkura, B., Zunft, H.J. and Blaut, M. (1997) Effects of Inulin and Lactose on Fecal Microflora, Microbial Activity, and Bowel Habit in Elderly Constipated Persons. American Journal of Clinical Nutrition, 65, 1397-1402.

[45] Yen, C.H., Kuo, Y.W., Tseng, Y.H., Lee, M.C. and Chen, H.L. (2011) Beneficial Effects of Fructo-Oligosaccharides Supplementation on Fecal Bifidobacteria and Index of Peroxidation Status in Constipated Nursing-Home ResidentsA Placebo-Controlled, Diet-Controlled Trial. Nutrition, 27, 323-328. http://dx.doi.org/10.1016/j.nut.2010.02.009 
[46] Agrawal, A., Houghton, L.A., Morris, J., Reilly, B., Guyonnet, D., Feuillerat, N.G., Schlumberger, A., Jakob, S. and Whorwell, P.J. (2009) Clinical Trial: The Effects of a Fermented Milk Product Containing Bifidobacterium lactis DN-173 010 on Abdominal Distension and Gastrointestinal Transit in Irritable Bowel Syndrome with Constipation. Alimentary Pharmacology \& Therapeutics, 29, 104-114. http://dx.doi.org/10.1111/j.1365-2036.2008.03853.x

[47] Koebnick, C., Wagner, I., Leitzmann, P., Stern, U. and Zunft, F. (2003) Probiotic Beverage Containing Lactobacillus casei Shirota Improves Gastrointestinal Symptons in Patients with Chronic Constipation. Canadian Journal of Gastroenterology, 17, 655-659.

[48] Ouwehand, A.C., Langström, H., Suomalainena, T. and Salminen, S. (2002) Effect of Probiotics on Constipation, Fecal Azoreductase Activity and Fecal Mucin Content in the Elderly. Annals Nutrition and Metabolism, 46, 159-162. http://dx.doi.org/10.1159/000063075

[49] Amenta, M., Cascio, M.T., Di Fiore, P. and Venurini, I. (2006) Diet and Chronic Constipation. Benefits of Oral Supplementation with Symbiotic Zirfos (Bifidobacterium longumW11 + FOS Actilight). Acta Biomedica, 77, 157-162.

[50] Waitzberg, D.L., Logullo, L.C., Bittencourt, A.F., Torrinhas, R.S., Shiromab, G.M., Paulino, N.P. and Teixeira-daSilva, M.L. (2012) Effect of Synbiotic in Constipated Adult Women-A Randomized, Double-Blind, Placebo-Controlled Study of Clinical Response. Clinical Nutrition, 32, 27-33.

[51] Ojansivu, I., Ferreira, C.L. and Salminen, S. (2011) Yacon, New Source of Prebiotic Oligosaccharides with a History of Safe Use. Trends of Food Science and Technology, 22, 40-46. http://dx.doi.org/10.1016/j.tifs.2010.11.005

[52] Lachman, J., Fernandez, E.C. and Orsak, M. (2003) Yacon Smallanthus sonchifolia (Poepp. et Endl.) H. Robinson Chemical Composition and Use-A Review. Plant, Soil and Environment, 49, 283-290.

[53] Genta, S., Cabrera, W., Habib, N., Pons, J., Carillo, I.M., Grau, A. and Sánchez, S. (2009) Yacon Syrup: Beneficial Effects on Obesity and Insulin Resistance in Humans. Clinical Nutrition, 28, 182-187. http://dx.doi.org/10.1016/j.clnu.2009.01.013

[54] Rodrigues, V.C. (2011) Formulação, índice glicêmico e aplicação alimentar de um produto à base de yacon (Smallanthus sonchifolius). Tesis, 89p.

[55] Valentova, K., Stejskal, D., Bartek, J., Dvořáčkováa, S., Křen, V., Šimánek, V. and Ulrichová, J. (2008) Maca [Lepidium meyenii] and Yacon [Smallanthus sonchifolius] in Combination with Silymarin as Food Supplements: In Vivo Safety Assessment. Food and Chemical Toxicology, 46, 1006-1013. http://dx.doi.org/10.1016/j.fct.2007.10.031

[56] Rodrigues, F.C. (2011) Avaliação da farinha de yacon (Smallanthus sonchifolius) na modulação das propriedades biomecânicas e na retenção de minerais nos ossos de ratos wistar. Tesis, 180p.

[57] Lobo, A., Colli, C., Alvares, E.P. and Filisetti, T.M. (2007) Effects of Fructans-Containing Yacon (Smallanthus sonchifolius Poepp \& Endl.) Flour on Caecum Mucosal Morphometry, Calcium and Magnesium Balance, and Bone Calcium Retention in Growing Rats. British Journal of Nutrition, 97, 776-785. http://dx.doi.org/10.1017/S0007114507336805

[58] Geyer, M., Manrique, I., Degen, L. and Beglinger, C. (2008) Effect of Yacon (Smallanthus sonchifolius) on Colonic Transit Time in Healthy Volunteers. Digestion, 78, 30-33. http://dx.doi.org/10.1159/000155214

\section{Abbreviations List}

FOS: fructooligosaccharides

GT: gastrointestinal tract

SCFA: short-chain fatty acids 
Scientific Research Publishing (SCIRP) is one of the largest Open Access journal publishers. It is currently publishing more than 200 open access, online, peer-reviewed journals covering a wide range of academic disciplines. SCIRP serves the worldwide academic communities and contributes to the progress and application of science with its publication.

Other selected journals from SCIRP are listed as below. Submit your manuscript to us via either submit@scirp.org or Online Submission Portal.
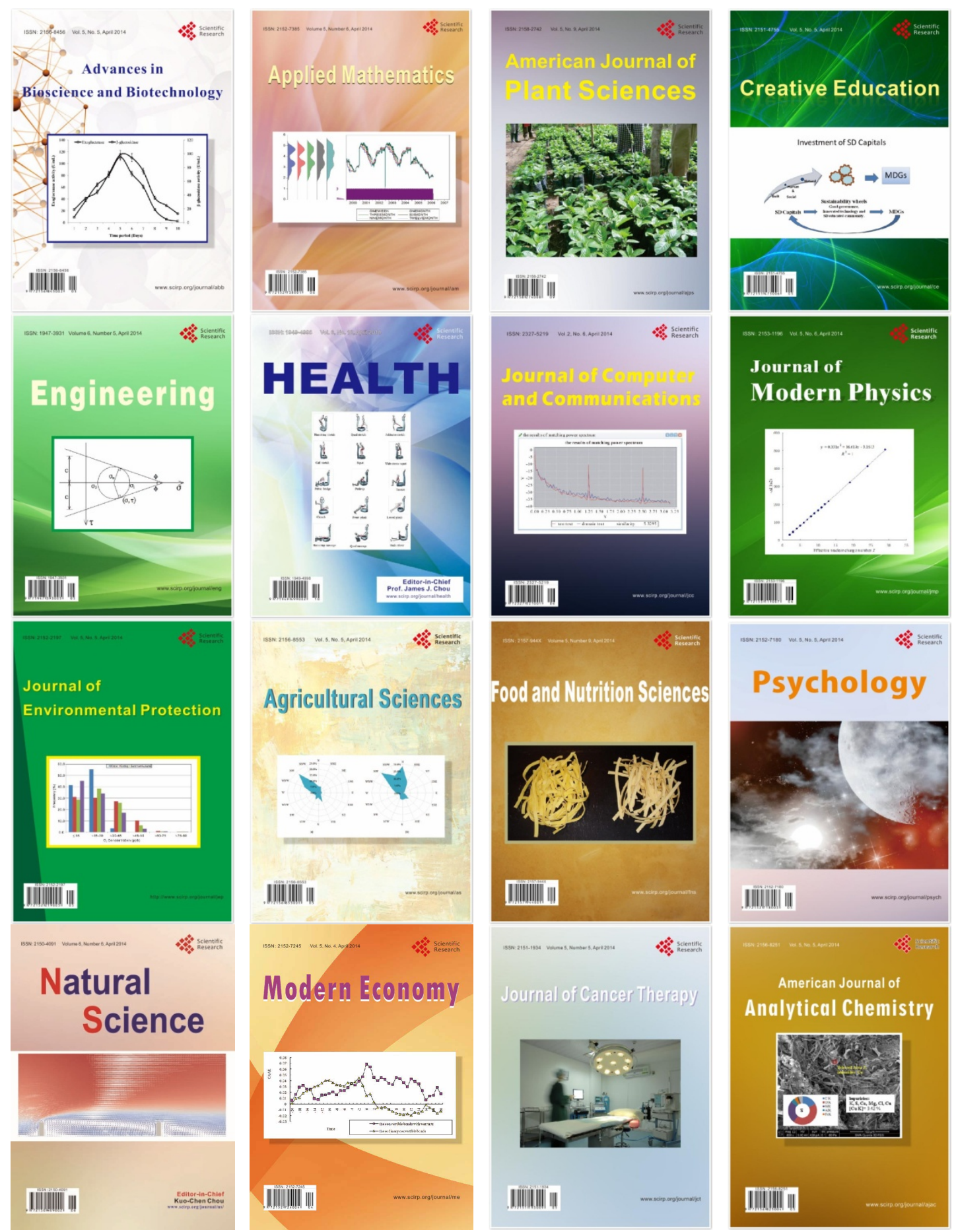